\title{
Uji Isolat Bakteri Azotobacter Asal Kebun Lidah Buaya dengan Pupuk Urea terhadap Serapan Nitrogen pada Tanaman Kedelai (Glycine Max L.) di Tanah Gambut
}

\section{Test of Azotobacter Bacteria Isolate from Aloe Vera Garden with Urea Fertilizer on Nitrogen Uptake in Soybean Plants (Glycine Max L.) in Peat Soil}

\author{
Nandung Erlanda ${ }^{1}$, Feira B. Arief ${ }^{2}$, Ismahan Umran ${ }^{3}$, Sutarman Gafur ${ }^{4}$, Denah Suswati ${ }^{5}$ \\ ${ }^{1,2}$ Program Studi Ilmu Tanah, Fakultas Pertanian, Universitas Tanjungpura \\ ${ }^{3,4,5}$ Dosen Program Studi Ilmu Tanah, Fakultas Pertanian, Universitas Tanjungpura
}

\begin{tabular}{|c|c|}
\hline ARTICLE INFO & ABSTRACT \\
\hline Article history: & $\begin{array}{l}\text { Azotobacter nitrogen-fixing bacteria and urea fertilizer to reduce excessive } \\
\text { use of chemical fertilizers. These bacteria can play a role in increasing }\end{array}$ \\
\hline DOI: & nitrogen uptake and further growth of soybean plants. This study aimed to \\
\hline 10.30595/pspfs.v2i.183 & $\begin{array}{l}\text { obtain growth media for Azotobacter and increase plant and root growth } \\
\text { and nitrogen uptake of Biosoy soybean varieties. The research was }\end{array}$ \\
\hline $\begin{array}{l}\text { Submitted: } \\
\text { July } 29,2021\end{array}$ & $\begin{array}{l}\text { conducted to help the uptake of } n \text { in the soil and reduce the excessive use } \\
\text { of chemical fertilizers. The first experiment was carried out by growing } \\
\text { bacteria on the media for } 120 \text { hours. The second experiment was designed }\end{array}$ \\
\hline Accepted: & in a completely randomized design that tested two treatments with \\
\hline Sept 10, 2021 & $\begin{array}{l}\text { additional use of urea fertilizer and Azotobacter and no Azotobacter. The } \\
\text { results showed that there was no effect of giving Azotobacter from aloe }\end{array}$ \\
\hline Published: & vera gardens, and urea fertilizer showed a significant effect on the observed \\
\hline Nov 10, 2021 & $\begin{array}{l}\text { variables of soil } \mathrm{pH} \text { in soybean plants on peat soil. In contrast, the variables } \\
\text { observed were population, plant height, } \mathrm{N} \text { content, N-total, plant dry }\end{array}$ \\
\hline Keywords: & $\begin{array}{l}\text { weight, dry weight of plant roots, and } \mathrm{N} \text { span of soybean plants had no } \\
\text { significant effect. }\end{array}$ \\
\hline
\end{tabular}

This work is licensed under a Creative Commons Attribution 4.0 International License.

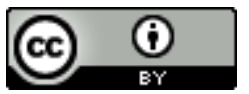

Corresponding Author:

Feira B. Arief

Program Studi Ilmu Tanah, Fakultas Pertanian

Universitas Tanjungpura

Email: feirabarief@gmail.com

\section{PENDAHULUAN}

Tanah gambut terutama yang berada di daerah tropis memiliki sifat fisika, kimia dan biologi tertentu yang mencerminkan ciri khas dari tanah tersebut. Disamping itu, sifat lain yang juga dimiliki adalah kandungan bahan organik yang tinggi karena dalam pembentukannya terdapat tanaman air dan vegetasi lahan basah yang mati dan melapuk secara bertahap membentuk lapisan dan terperangkap selama beberapa waktu (Agus dan Subiksa, 2008). Tingginya kandungan bahan organik dan rendahnya $\mathrm{pH}$ menyebabkan unsur-unsur hara yang berada dalam tanah tidak bisa langsung di manfaatkan oleh tumbuhan karena unsur-unsur tersebut mengalami kekurangan zat unsur tertentu, oleh karena itu, hanya beberapa jenis tumbuhan saja yang dapat hidup pada tanah gambut.

Tanah gambut adalah lahan yang memiliki lapisan tanah kaya bahan organik (C-organik > 18\%) dengan ketebalan $50 \mathrm{~cm}$ atau lebih. Bahan organik penyusun tanah gambut terbentuk dari sisa-sisa tanaman yang belum 
melapuk sempurna karena kondisi lingkungan jenuh air dan miskin hara. Gambut adalah bahan organik mati yang telah terbentuk di tempat yang tetap. Gambut terdiri dari $90 \%$ air dan $10 \%$ tumbuhan.

Tanaman kedelai umumnya tumbuh tegak berbentuk semak dan merupakan tanaman semusin dapat mencapai ketinggian antara 30-100 cm. morfologi tanaman kedelai didukung oleh komponen utamanya yaitu akar, daun batang, polong dan biji. Bagian batang tanaman kedelai beruas-ruas dan memiliki percabangan antara 3-6 cabang (Cahyono, 2002). Kedelai yang ditanam pada tanah subur pada umumnya dapat menghasilkan antara 100-200 polong/pohon umur keluarnya bunga tergantung pada varietas kedelai pengaruh suhu dan penyinaran matahari. Tanaman kedelai menghendaki penyinaran pendek, \pm 12 jam perhari.

Tanaman Kedelai (Glycine max L.) merupakan komoditi pangan utama setelah padi dan jagung. Menurut Badan pusat statistik (BPS), hasil produksi kedelai Provinsi Kalimantan Barat pada tahun 2014, hasil produksi kedelai mencapai 3.161 ton sedangkan pada tahun 2017 hasil produksi kedelai hanya mencapai 451 ton. Hasil produksi kedelai mengalami penurunan pada tahun 2017 sehingga perlu dilakukan inovasi baru untuk meningkatkan produksi kedelai. Produktivitas kedelai dapat ditingkatkan melalui teknik budidaya maupun dalam pemupukan. Urea merupakan salah satu pupuk yang memiliki kandungan nitrogen.

Pupuk urea adalah pupuk yang mengandung nitrogen $(\mathrm{N})$ berkadar tinggi. Unsur hara nitrogen merupakan zat hara yang sangat diperlukan tanaman. Unsur nitrogen di dalam pupuk urea sangat bermanfaat bagi tanaman untuk pertumbuhan dan perkembangan. Manfaat lainnya antara lain pupuk urea membuat daun tanaman lebih hijau, rimbun, dan segar. Unsur hara nitrogen juga membantu tanaman sehingga mempunyai banyak zat hijau daun (klorofil). Dengan adanya zat hijau daun yang berlimpah, tanaman akan lebih mudah melakukan fotosintesis, pupuk urea juga mempercepat pertumbuhan tanaman (tinggi, jumlah anakan, cabang dan lain-lain) serta, pupuk urea juga mampu menambah kandungan protein di dalam tanaman (Suhartono, 2012).

Bakteri Azotobacter adalah bakteri penambat nitrogen bebas $\left(\mathrm{N}_{2}\right.$ dari udara) yang mampu menghasilkan substansi zat pemacu tumbuh giberelin, sitokinin, dan asam indol asetat, sehingga dapat memacu pertumbuhan akar (Nosrati et al., 2014). Bakteri Rhizobium, Azotobacter, dan Azospirillum akan membantu mengubah $\mathrm{N}_{2}$ dari udara menjadi $\mathrm{NH}_{3}$ dengan menggunakan enzim nitrogenase, kemudian $\mathrm{NH}_{3}$ diubah menjadi glutamin dan alanin (Ward \& Jensen 2014), sehingga dapat diserap oleh tanaman. Azotobacter sp. merupakan spesies rizobacteri yang dikenal sebagai agen penambat nitrogen yang mengkonversi dinitrogen $\left(\mathrm{N}_{2}\right)$ ke dalam bentuk amonium $\left(\mathrm{NH}_{3}\right)$, mampu menambat nitrogen dalam jumlah yang cukup tinggi.

Azotobacter merupakan bakteri aerob yang menerima energi dari reaksi redoks dengan menggunakan senyawa organik sebagai donor elektron. Nilai $\mathrm{pH}$ optimum untuk pertumbuhan dan fiksasi nitrogen Azotobacter sp. berkisar antara 7-7,5, namun pertumbuhannya dapat tetap berlangsung pada $\mathrm{pH}$ 4,8-8,5. Azotobacter juga dapat tumbuh secara mixotroph, yakni dalam medium nitrogen-free yang mengandung mannosa. Azotobacter dapat hidup pada karbohidrat yang variatif, alkohol, dan asam organik, serta metabolismenya oksidatif. Pada atmosfer nitrogen dalam bentuk molekul dan gas dinitrogen $\left(\mathrm{N}_{2}\right)$ sangat berlimpah sekitar $80 \%$ dari total gas atmosfer, namun tidak dapat langsung digunakan untuk proses metaboilsme oleh tanaman tingkat tinggi atau binatang. Bentuk nitrogen yang dapat diambil oleh tanaman dari tanah adalah nitrat $\left(\mathrm{NO}_{3}{ }^{-}\right)$dan amonium $\left(\mathrm{NH}_{4}{ }^{+}\right)$(Barber, 1984; Tisdale et al., 1985 "dalam" Danaptriatna, 2010). Kedua bentuk nitrogen tersebut sebagian besar berasal dari pupuk dan penambatan nitrogen udara oleh mikroba tanah (Danaptriatna, 2010).

\section{METODE PENELITIAN}

Penelitian ini dilaksanakan di Green House Fakultas Pertanian Universitas Tanjungpura. Analisis populasi dan identifikasi pada tanah dilakukan Laboratorium Biologi dan Bioteknologi Tanah dan analisis kimia tanah dilakukan di Laboratorium Kimia dan Kesuburan Tanah Fakultas Pertanian Universitas Tanjungpura. Penelitian ini direncanakan kurang lebih 7 bulan dimulai dari penyiapan sampel hingga pembahasan skripsi. Analisis Data Penelitian ini menggunakan Rancangan Acak Lengkap (RAL) pola faktorial dengan program SPSS For Windows 24.

Model Statistik percobaan pola faktorial dengan RAL adalah sebagai berikut: Bakteri penambat nitrogen (azotobacter) diberikan dengan 2 perlakuan:

$\mathrm{A}_{0}$ : Tidak diberi bakteri azotobacter

$\mathrm{A}_{1}$ : Diberi bakteri azotobacter

Pupuk urea masing-masing diberikan perlakuan sebagai berikut:

$\mathrm{U}_{0}:$ tanpa pemberian pupuk urea $(0 \mathrm{~kg} / \mathrm{ha})$

$\mathrm{U}_{1}: 5 \mathrm{gram} /$ polybag pupuk urea $(5 \mathrm{~kg} / \mathrm{ha})$

$\mathrm{U}_{2}: 10 \mathrm{gram} /$ polybag pupuk urea $(10 \mathrm{~kg} / \mathrm{ha})$

$\mathrm{U}_{3}: 15$ gram/polybag pupuk urea $(15 \mathrm{~kg} / \mathrm{ha})$ 


\section{HASIL DAN PEMBAHASAN}

Data analisis keragaman hasil pengukuran tinggi tanaman saat kedelai berumur 2, 3, 4 dan 5 minggu seteleh tanam dapat dilihat pada lampiran. Hasil analisis menyatakan bahwa pengaruh pemberian isolat bakteri azotobacter lidah buaya dan pupuk urea tidak berpengaruh nyata dan tidak adanya intreksi antara bakteri azotobacter lidah buaya dan pupuk urea.

Berdasarkan hasil analisis keragaman tinggi tanaman kedelai yang menunjukkan tidak adanya pengaruh nyata terhadap pemberian bakteri azotobacter asal kebun lidah buaya dan pupuk urea dapat dilihat pada Tabel 3 . Hal ini diduga dipengaruhi faktor lingkungan seperti cahaya matahari, suhu, kelembabban tanaman kedelai selama proses pertumbuhan dan kekurangan dalam pemberian air yang memperngaruh konsentrasi hara laruta tanah dan laju pergerakan akar melalui difusi dan transport. Kondisi tanah sedikit padat menyebabkan aerasi tanah terganggu sehingga pertukaran oksigen kurang lancar. Diduga kemungkinan akar tanaman berada dalam keadaan kekurangan oksigen. Gardner et al (1991) mengatakan kebutuhan oksigen pada tanaman kedelai lebih besar pada masa vegetatif maksimum. Berkurangnya oksigen menyebabkan kegiatan respirasi rendah dan energi yang dihasilkan sedikit sehingga penyerapan air unsur hara juga rendah akibatnya pertumbuhan tanaman menjadi lebih baik.

Tabel 3. Analisis Keragaman Pengaruh Isolat Bakteri Bakteri aztobacter Asal Kebun Lidah Buaya dan Urea Terhadap Tinggi Tanaman Kedelai

\begin{tabular}{|c|c|c|c|c|c|}
\hline \multirow{3}{*}{ SK } & \multirow{3}{*}{$\mathrm{Db}$} & \multicolumn{4}{|c|}{ Tinggi Tanaman } \\
\hline & & Minggu 2 & Minggu 3 & Minggu 4 & Minggu 5 \\
\hline & & (sig) & $(\operatorname{sig})$ & $(\operatorname{sig})$ & $(\operatorname{sig})$ \\
\hline Urea & 1 & $0,65^{\mathrm{tn}}$ & $0,95^{\mathrm{tn}}$ & $0,68^{\text {tn }}$ & $0,42^{\text {tn }}$ \\
\hline Bakteri azotobacter & 3 & $0,70^{\text {tn }}$ & $0,73^{\text {tn }}$ & $0,82^{\mathrm{tn}}$ & $0,71^{\mathrm{tn}}$ \\
\hline Urea*bakteri Azotobacter & 3 & $0,44^{\text {tn }}$ & $0,34^{\mathrm{tn}}$ & $0,38^{\text {tn }}$ & $0,31^{\mathrm{tn}}$ \\
\hline Galat & 16 & & & & \\
\hline Sig $\propto$ & & $\propto 0,05$ & $\propto 0,05$ & $\propto 0,05$ & $\propto 0,05$ \\
\hline
\end{tabular}

Catatan:
tn : tidak berpengaruh nya $\propto=0,05$
$n:$ berpengaruh nyata $\propto=0,05$

Tabel 4. Pengaruh Bakteri Bakteri aztobacter Asal Kebun Lidah Buaya dan Urea Terhadap Tinggi Tanaman Kedelai

\begin{tabular}{|c|c|c|c|}
\hline \multirow[t]{2}{*}{ SK } & \multirow[t]{2}{*}{$\mathrm{Db}$} & $\begin{array}{c}\text { Berat Kering } \\
\text { Akar }\end{array}$ & $\begin{array}{c}\text { Berat Kering } \\
\text { Tanaman }\end{array}$ \\
\hline & & (sig) & $(\operatorname{sig})$ \\
\hline Urea & 1 & $0,64^{\text {tn }}$ & $0,42^{\text {tn }}$ \\
\hline Bakteri azotobacter & 3 & $0,93^{\mathrm{tn}}$ & $0,71^{\text {tn }}$ \\
\hline Urea*bakteri azotobacter & 3 & $0,21^{\mathrm{tn}}$ & $0,31^{\text {tn }}$ \\
\hline Galat & 16 & & \\
\hline Sig $\propto$ & & $\propto 0,05$ & $\propto 0,05$ \\
\hline
\end{tabular}

Catatan:
tn : tidak berpengaruh nya $\propto=0,05$
$n:$ berpengaruh nyata $\propto=0,05$

Berdasarkan hasil analisis keragaman berat kering akar pada Tabel 4, pemberian bakteri azotobacter asal kebun lidah buaya dan pupuk urea menunjukkan tidak adanya berpengaruh nyata. Tanaman yang kekurangan unsur hara akan mengalami sistem perakaran yang pendek dan sedikit bercabang sehingga daya serap terhadap unsur hara berkurang dan berpengaruh terhadap berat kering tanaman. Akar sebagai organ vegetatif terpenting bagi tanaman yang berperan dalam menyerap unsur hara, air, mineral dan nutrisi lainya dari dalam tanah. Sistem perakaran tanaman dikendalikan oleh sifat genetis dari tanaman yang bersangkutan dan kondisi tanah atau 
media tumbuh tanaman sementara pola penyebaran akar dipengaruhi faktor penghalang mekanis, suhu tanah aerasi, ketersedian air dan ketersedian unsur hara.

Berdasarkan hasil analisis keragaman berat kering tanaman kedelai pada Tabel 4 yang menunjukkan tidak adanya pengaruh nyata terhadap pemberian bakteri azotobacter asal kebun lidah buaya dan pupuk urea. Berat kering tanaman mencerminkan pertumbuhan tanaman dan banyaknya unsur hara yang terserap per satuan bobot biomassa yang dihasilkan. Semakin tinggi nilai berat kering tanaman yang dihasilkan, maka pertumbuhan tanaman semakin baik dan unsur hara yang terserap semakin banyak. Berat kering tanamn berhubungan dengan peningkatkan penyerapan unsur hara yang meningkatkan proses fotosintesis. Hasil fotosintesis tersebut akan digunakan tanaman untuk membentuk sebagai energi metabolism, senyawa sel aktif membentuk struktur tumbuh dan cadangan makan, sehingga memberikan pengaruh terhadap hasil tanaman (Garder, et al 1991). Tanaman yang diberi unsur $\mathrm{N}$ secara cukup, maka pembentukkan klorofilnya akan optimal, sehingga proses fotosintesis akan berjalan dengan baik. Ketersediaan unsur N yang cukup akan memberikan hasil yang baik untuk pertumbuhan. Ketersediaan unsur $\mathrm{N}$ dalam tanah menjadi faktor pembatas pertumbuhan tanaman, sehingga meskipun kondisi unsur hara lainnya, seperti $\mathrm{P}$ dan $\mathrm{K}$ sudah cukup tersedia dalam tanah, hal tersebut masih memberikan kemungkinan berat kering suatu tanaman dapat menurun. Dalam penelitian ini didapatkan hasil bahwa komposisi inokulan bakteri penambat nitrogen dan pupuk urea tidak memberikan pengaruh dalam pertumbuhan tinggi tanaman dan berat kering tanaman.

Berdasarkan hasil analisis keragaman yang dapat dilihat pada Tabel 5 menunjukkan bahwa tidak adanya pengaruh nyata terhadap pemberian bakteri azotobacter asal kebun lidah buaya dan pupuk urea terhadap nilai serapan $\mathrm{N}$ tanaman. Berdasarkan serapan $\mathrm{N}$ (nitrogen) tanaman kedelai dilakukan pada saat mencapai fase vegetatif maksimum yang ditandai dengan muculnya bunga berkisar $80 \%$ dari jumlah tanaman. Serapan $\mathrm{N}$ tanaman ditentukan oleh $\mathrm{NO}_{3}{ }^{-}$dan $\mathrm{NH}_{4}{ }^{+}$yang pasokannya dipengaruhi oleh $\mathrm{N}$-total tanah. Meskipun demikian, ternyata jumlah $\mathrm{N}$-total yang meningkat seiring dengan meningkatnya pemberian pupuk $\mathrm{N}$ tidak menyebabkan pasokan $\mathrm{NO}_{3}{ }^{-}$dan $\mathrm{NH}_{4}^{+}$tersedia bagi tanaman. Hal tersebut diduga karena sifat $\mathrm{N}$ yang mudah tercuci dan menguap. Selain itu, kurangnya cahaya matahari juga diduga menyebabkan kurangnya pasokan $\mathrm{N}$ yang terserap pencahayaan $70 \%$ karena tanaman kedelai termasuk tanaman yang memerlukan sinar matahari cukup panjang sehingga berpengaruh terhadap laju fotosintesis.

Tersedianya $\mathrm{N}$ dari Urea hanya dalam jangka pendek, akibatnya hara yang dapat dimanfaatkan tanaman hanya sebagian kecil saja dan sebagian lagi kembali ke udara. Hal ini berhubungan dengan sifat Urea yang higroskopis, mudah larut dalam air dan bereaksi dengan cepat, juga mudah menguap dalam bentuk amino. Menurut Keda (1991), penyerapan N oleh tanaman dipengaruhi oleh faktor lingkungan seperti suhu tanah, suhu udara, aerasi, $\mathrm{pH}$, komposisi unsur hara lain dan spesies tanaman itu sendiri.

Tabel 5. Pengaruh Bakteri Bakteri aztobacter Asal Kebun Lidah Buaya dan Urea Terhadap Tinggi Tanaman Kedelai

\begin{tabular}{|c|c|c|c|c|c|}
\hline SK & $\mathrm{Db}$ & $\begin{array}{c}\text { Kadar } \\
\text { Nitrogen }\end{array}$ & $\begin{array}{c}\mathrm{pH} \\
\text { Tanah }\end{array}$ & $\begin{array}{c}\text { Serapan } \\
\text { Tanaman }\end{array}$ & $\begin{array}{c}\text { Populasi } \\
\text { Bakteri } \\
\text { Azotobacter }\end{array}$ \\
\hline & & $(\operatorname{sig})$ & $(\operatorname{sig})$ & $(\operatorname{sig})$ & $(\operatorname{sig})$ \\
\hline Urea & 1 & $0,19^{\mathrm{tn}}$ & $0,00^{\mathrm{n}}$ & $0,62^{\mathrm{tn}}$ & $0,35^{\mathrm{tn}}$ \\
\hline Bakteri azotobacter & 3 & $0,66^{\mathrm{tn}}$ & $0,05 \mathrm{n}$ & $0,66^{\mathrm{tn}}$ & $0,77^{\mathrm{tn}}$ \\
\hline Urea*bakteri azotobacter & 3 & $0,41^{\mathrm{tn}}$ & $0,39^{\mathrm{tn}}$ & $0,90^{\text {tn }}$ & $0,52^{\mathrm{tn}}$ \\
\hline Galat & 16 & & & & \\
\hline Sig $\propto$ & & $\propto 0,05$ & $\propto 0,05$ & $\propto 0,05$ & $\propto 0,05$ \\
\hline
\end{tabular}

\section{Catatan:}

th : tidak berpengaruh nya $\propto=0,05$

$n:$ berpengaruh nyata $\propto=0,05$

Berdasakan hasil analisis kadar $\mathrm{N}$ pada Tabel 5 menunjukkan bahwa tidak adanya pengaruh nyata terhadap perlakuan pemberian pemberian bakteri azotobacter asal kebun lidah buaya dan pupuk urea terhadap tanaman kedelai. Nitrogen yang dikandung tanah pada umumnya rendah, sehingga harus selalu ditambahkan dalam bentuk pupuk atau sumber lainnya pada setiap awal pertanaman. Selain kadarnya rendah, $\mathrm{N}$ di dalam

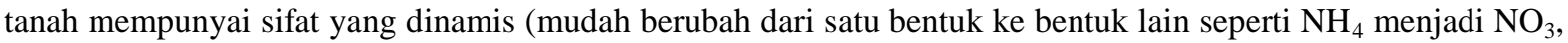
$\mathrm{NO}, \mathrm{N}_{2} \mathrm{O}$ dan $\mathrm{N}_{2}$ ) dan mudah hilang menguap dan tercuci bersama air drainase (Setyorini, et al, 2006).

Berdasarkan hasil analisis keragaman N-total pada Tabel 5 yang menunjukkan tidak adanya pengaruh nyata terhadap pemberian bakteri azotobacter asal kebun lidah buaya dan pupuk urea. Tinggi rendahnya kandungan $\mathrm{N}$ dalam tanah dipengaruhi oleh jumlah masukan maupun kehilangan dalam siklus $\mathrm{N}$ (Khalif et al., 
2014). Hal ini sesuai dengan pendapat Firmansyah dan Sumarni (2013) menyatakan bahwa peningkatan kandungan N-total pada tanah dapat disebabkan karena adanya penyerapan nilai kuantitas N-total pada pupuk oleh tanah. Penurunan kandungan N-total tanah gambut dapat disebabkan karena terjadinya immobilisasi nitrogen yaitu mikroorganisme (fungi atau bakteri) yang memanfaatkan $\mathrm{N}$ untuk menguraikan protein dan terjadinya penguapan nitrogen ke udara bebas. Tersedianya $\mathrm{N}$ dalam tanah sangat dipengaruhi oleh $\mathrm{pH}$ tanah, dimana $\mathrm{pH}$ masam berpengaruh terhadap tersedianya unsur bagi tanah dan tanaman.

Tabel 6. Analisis Uji Beda Nyata Jujur Pengaruh Pupuk Urea Terhadap pH

\begin{tabular}{cc}
\hline Urea & Rata-rata \\
\hline U3 & $5.74 \mathrm{a}$ \\
U2 & $5.80 \mathrm{a}$ \\
$\mathrm{U} 1$ & $5.91 \mathrm{ab}$ \\
$\mathrm{U} 0$ & $6.09 \mathrm{c}$ \\
\hline BNJ 5\% & 0.15 \\
\hline
\end{tabular}

Keterangan : Angka yang diikuti yang sama menunjukkan berbeda nyata pada uji BNJ taraf 5\%

Hasil analisi BNJ menunjukan berbeda nyata pada pemberian pupuk urea pada perlakuan U0 dengan dosis 0 gram/polybag, dengan semua perlakuan lainnya.

Tabel 7. Analisis Uji Beda Nyata Jujur Pengaruh Isolat Bakteri Azotobacter Terhadap pH

\begin{tabular}{cc}
\hline Bakteri & Rata-rata \\
\hline A0 & $5.84 \mathrm{a}$ \\
A1 & $5.93 \mathrm{~b}$ \\
\hline BNJ & 0.09
\end{tabular}

Keterangan : Angka yang diikuti yang sama menunjukkan berbeda tidak nyata pada uji BNJ taraf 5\%

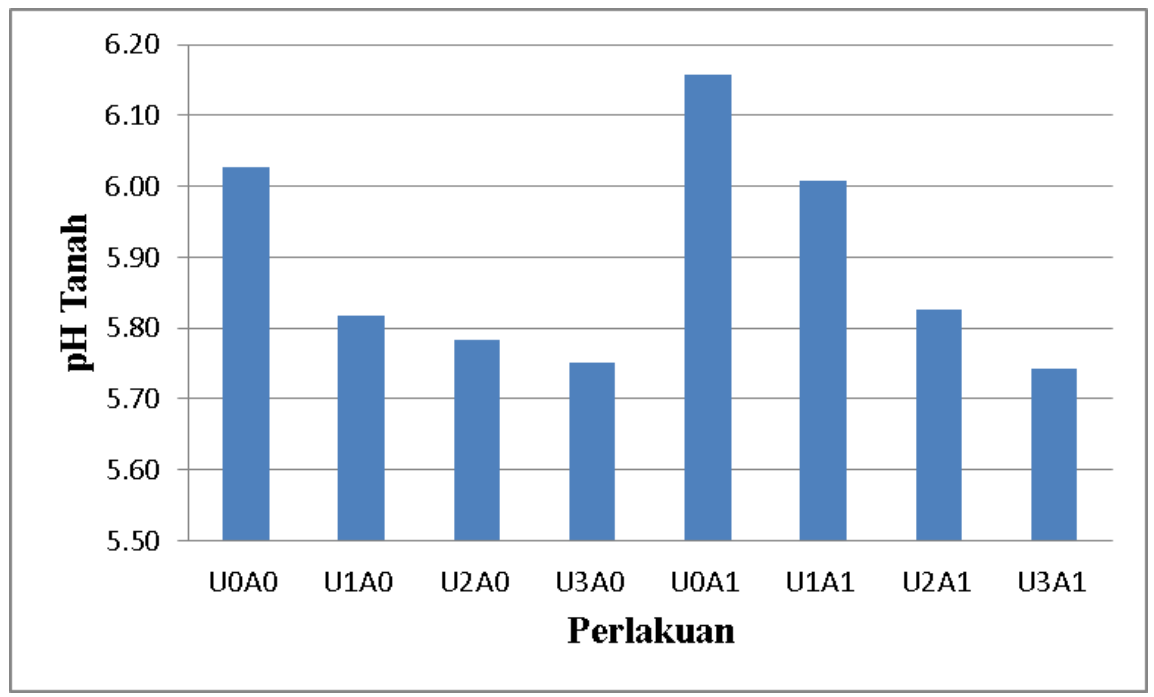

Gambar 1. pH Tanah Pengaruh Pemberian Bakteri Azotobacter Dan Pupuk Urea

Berdasarkan hasil analisis $\mathrm{pH}$ tanah pada Tabel 5 dapat diketahui bahwa penambahan bakteti azotobacter pada tanah gambut berpengaruh nyata, sedangkan dengan penambahan pupuk urea berpengaruh nyata. Dapat diliat pada Gambar 1 dengan nilai rata-rata setiap perlakuan pemberian bakteri azotobacter dengan ulangan U0A1 nilai $\mathrm{pH}$ yang lebih tinggi disbanding dengan pemberian pupuk urea pada ulangan U3A0 dengan nilai $\mathrm{pH}$ yang lebih redah. Berdasarkan uji BNJ pada Tabel 6 dan Tabel 7, menunjukkan adanya pengaruh nyata terhadap $\mathrm{pH}$ tanah dengan adanya pemberian pupuk urea dan bakteri pada tanaman. Penurunan $\mathrm{pH}$ tanah disebabkan karena mikroorganisme mengonsumsi unsur hara dalam jumlah yang banyak untuk pertumbuhannya dan mengeluarkan $\mathrm{CO}_{2}$ sehingga kadar $\mathrm{CO}_{2}$ bertambah di dalam tanah yang dapat menimbulkan penurunan $\mathrm{pH}$. Hal 
ini senada dengan pernyataan Hardjowigeno (2003) bahwa kemasaman tanah dapat dipengaruhi oleh mikroorganisme dalam penyerapan unsur sehingga dapat menurunkan nilai $\mathrm{pH}$ tanah menjadi masam. Hasil reaksi menyumbangkan banyaknya $\mathrm{H}^{+}$ini mengakibatkan jumlah $\mathrm{H}^{+}$bertambah dalam tanah berakibatkan $\mathrm{pH}$ menurun (masam). Ditegaskan dengan pernyataan Foth (1995) mengemukakan bahwa pupuk yang mengandung nitrogen dalam bentuk amonia atau dalam bentuk lainnya dapat berubah menjadi nitrat yang berakibat pada penurunan $\mathrm{pH}$ tanah. Ditegaskan dengan pernyataan Rini (2009) penurunan $\mathrm{pH}$ terjadi karena kation-kation basa dan unsur-unsur hara lainnya telah diserap oleh mikroorganisme dalam jumlah yang besar untuk pertumbuhan dan sebagian ada yang hilang tercuci oleh air, sehingga terjadi pertukaran kation-kation basa seperti $\mathrm{Ca}^{2+} \mathrm{dengan}$ ion $\mathrm{H}^{+}$pada koloid tanah.

Berdasarkan hasil analisi keragaman populasi bakteri azotobacter pemberian bakteri azotobacter asal kebun lidah buaya dan pupuk urea dapat dilihat pada Tabel 5 yang menunjukkan tidak berpengaruh nyata, dengan hasil analisi pH tanah masam 5,5-6,0 dengan tingkat kandungan unsur hara rendah N-total dalam tanah serta rendahnya jumlah populasi bakteri yang bekisar $\left(10^{3}-10^{5} \mathrm{cfu} / \mathrm{g}\right)$. Keadaan tanah seperti ini termasuk dalam katagori tanah tidak subur atau marginal. Menurut Obaton (1977) tanah yang subur akan mengandung jumlah populasi bakteri $\geq 10^{7}$ dan semakin tinggi populasi mikroba tanah, maka akan semakin tinggi aktivitas biokimia dalam tanah dan semakin tinggi pula indeks kualitas tanah (Karlen et al. 2006), khususnya dalam hal kesuburannya. Unsur hara yang cukup akan diikuti dengan pertumbuhan mikroba yang baik. Ketersediaan unsur hara yang kurang akan menjadi penghambat pertumbuhan sel mikroba. Nitrogen memainkan peran penting dalam metabolisme seluler khususnya dalam pembelahan sel, sehingga apabila kandungan nitrogennya semakin sedikit maka kemampuan bakteri untuk membelah menjadi semakin lambat.

\section{KESIMPULAN}

Berdasarkan hasil penelitian maka dapat diambil beberapa kesimpulan sebagai berikut:

1. Tidak adanya pengaruh interaksi antara pemberian isolat bakteri azotobacter dan pupuk urea tidak berpengaruh nyata terhadap serapan $\mathrm{N}$ pada tanaman kedelai.

2. Pemberian pupuk urea dan bakteri azotobacter menunjukkan tidak adanya pengaruh terhadap pertumbuhan tinggi tanaman, berat basah tanaman, berat kering tanaman, berat kering akar, kadar $\mathrm{N}$, dan $\mathrm{N}$-total.

3. Pemberian pupuk urea hanya berpengaruh nyata terhadap $\mathrm{pH}$ tanah dan pemberian azotobacter tidak berbeda nyata terhadap $\mathrm{pH}$ tanah.

\section{DAFTAR PUSTAKA}

Adisarwanto T, Subandi, dan Sudaryono, 2016, Teknologi Produksi Kedelai, Balai Penelitian Tanaman Kacang-kacangan dan Umbi-umbian, Malang, http://balitkabi.litbang.pertanian.go.id/wpcontent/uploads/2016/03/dele_10.titis_.pdf. diakses 14 februari 2018.

Adisarwanto T. 2008. Budidaya Kedelai Tropika. Penebar Swadaya. Jakarta

Agus, F. dan I.G. M. Subiksa. 2008. Lahan Gambut: Potensi untuk Pertanian dan Aspek Lingkungan. Balai Penelitian Tanah dan World Agroforestry Centre (ICRAF), Bogor,Indonesia.

Aly, M.M., H. El-Sayed, A. El-Sayed, S.D. Jastaniah. 2012. Synergistic effect between Azotobacter vinelandii and Streptomyces sp. isolated from saline soil on seed germination and growth of wheat plant. J. Am. Sci. 8:667-676.

Baldani, JI, Caruso Vera L, Baldani, LD, Silvia, R, Goi \& Dobereiner, J 1997, 'Recent advance in BNF with non-legume plants', Soil Biol. Biochem., vol. 29, no. 5-6, pp. 911-22.

BPS, 2014. Kalimantan Barat Dalam Angka. Badan Pusat Statistik Provinsi Kalimantan Barat.

Barber, S. A. 1984. Soil Chemistry and The Availability of Plant Nutrients. America Society of Agronomy. 22 hal.

Bora, C.Y., dan Murdolelono, B. 2006. Pengaruh pemupukan pada budidaya jagung Ahuklean di Besikama, Belu, NTT. Berita Biologi 8(1): 27-34.

Cahyono, B. 2007. Teknik Budidaya dan Analisis Usaha Tani. Penerbit Aneka Ilmu. Semarang.

Danapriatna N. 2010. “Biokimia Penambatan Nitrogen Oleh Bakteri Non Simbiotik." ZJurnal Agribisnis dan Pengembangan Wilayah Vol. 11-10.

Firmanto, B.H. 2011. Praktis Bercocok Tanam Kedelai Secara Intensif. Penerbit Angkasa. Bandung. 
Gardner, F. P., R. B. Pearce, dan R. L. Mitchell. 1991. Physiology of Crop Plants (diterjemahkan dari: Fisiologi Tanaman Budidaya, penerjemah: Herawati Susilo). Penerbit Universitas Indonesia. Jakarta. 428 hal.

Gardner, F. P., R. B. Pearce, dan R. L. Mitchell. 1991. Physiology of Crop Plants (diterjemahkan dari: Fisiologi Tanaman Budidaya, penerjemah: Herawati Susilo). Penerbit Universitas Indonesia. Jakarta. 428 hal.

Hakim, et al..1986.. Dasar-Dasar Ilmu Tanah. Universitas Lampung. Bandar Lampung.

Hanafiah AS, T Sabrina dan H Guchi. 2010. Biologi dan Ekologi Tanah. FP - USU, Medan.

Hardjowigeno, S. 2003. Ilmu Tanah. Jakarta: Akademika Pressindo.

James, E. and F.L. Olivares. 1997. Infection and colonization of sugarcane and other graminaceous plants by endophytic diazotrophicus. Plant Science. 17:77-119.

Karlen DL, Hurley EG, Mallarino AP. 2006. Crop rotation on soil quality at three northern corn/soybean belt location. Agron J 98: 484-495.

Keda, H 1991, 'Utilization of nitrogen by vegetable crops, JARQ', 25 (2): 117-24.

Lingga, P. dan Marsono. 2013. Petunjuk Penggunaan Pupuk. Penebar Swadaya. Jakarta.

Made, U. 2010. Respon berbagai populasi tanaman jagung manis (Zea mays sacharata Sturt.) terhadap pemberian pupuk urea. J. Agroland 17 (2) : 138-143.

Manurung Rian Hardiansyah, Lahuddin Musa, dan Fauzi. 2014. Pengaruh Pemberian Kompos Kulit Durian pada Typic Hydraquent, Umbrik Dystrudept, dan Typic Kandiudult Terhadap Beberapa Aspek Kesuburan Tanah (pH, C Organik, dan N Total Serta Produksi Tanaman Jagung (Zea mays L.). Jurnal Online Agroteknologi. Universitas Sumatera Utara, Medan 2 (3): 1014-1-21 hlm.

Maryati. 2007. Serapan Nitrogen dan Fosfor Tanaman Bunga Matahari yang di Pupuk Urea dan SP-36 pada Tanah Ultisol. Jurnal Agrista, 11(1): 21-28.

Nosrati, R., P. Owlia, H. Saderi, I. Rasooli \& MA. Malboobi. 2014. Phosphate solubi lization characteristics of efficient nitro gen fixing soil Azotobacter strains Iran. Journal Microbiology 6 : 285-295.

Noor, M. 2001. Pertanian Lahan Gambut. Kanisius. Yogyakarta.

Obaton M. 1977. Effectivenes, Saprophitic and competitive Ability three properties of Rhizobium essensial for in-cresing the yield of inoculated legumes. In: Ayanaba A, Dart PJ (eds.) Biological Nitrogen Fixation in Farming Systems of the Tropics. John Wiley \& Sons, New York.

Pitijo, S. 2007. Benih Kedelai. Kanisius. Yogyakarta. 83 hal

Rahmawati Risma. 2018. Pengaruh Fosfor dan Nitrogen pada Bobot Serta Mutu Benih Tanaman Kedelai (glycine max L). Jurnal Agroteknologi. Lampung.

Rini, N. Hazli, S. Hamzar, dan B.P. Teguh. 2009. Pemberian Fly Ash Pada Lahan Gambut Untuk Mereduksi Asam Humat dan Kaitannya Terhadap Kalsium (Ca) Dan Magnesium (Mg). Jurnal Teroka. 9(2): 143154.

Sanchez, P.A. 1992. Sifat dan pengelolaan tanah tropika. Buku 2. Terjemahan Properties and Management in The Tropics. ITB, Bandung.

Saraswati, R dan Sumarno. 2008. Pemanfaatan Mikroba Penyubur Tanah Sebagai Komponen Teknologi Pertanian. Jurnal Iptek Tanaman Pangan, 3(1) :41- 58.

Setyorini, D., Didi, A. Rasti, S. Diah, S. 2006. Pupuk Organik dan Pupuk Hayati. Balai Besar Litbang Sumberdaya Lahan Pertanian Badan Penelitian dan Pengembangan Pertanian. Bogor.

Suhartono, 2012, Unsur-unsur nitrogen dalampupuk urea, UPN Veteran Yogyakarta.

Soehermanto. 2014. Respon Pertumbuhan dan Hasil Kedelai (Glicine Max L.) terhadap Pemberian Pupuk Cair Lewat Akar dan Daun pada Tanah Gambut dan Tanah Podsolik. Skripsi. Fakultas Pertanian. Universitas Palangkaraya.

Tisdale, S. L., Nelson, W. L., and Beaton, J. L. 1985. Soil Fertility and Fertlizer 4th Edition. The Mac Millan Publ. Co. New York. 754 p.

Proceedings homepage: https://conferenceproceedings.ump.ac.id/index.php/pspfs/issue/view/9 
Wahyunto, S. Ritung, Suparto, dan H. subagyo, 2005. Sebaran Gambut dan Kandungan Karbon di Sumatera dan Kalimantan. Proyek Climate Change, Foresta, and Peatlands in Indonesia. Wetlands International. Indonesia Programme dan Widlife Habitat Canada. Bogor.

Ward, BB., \& MM. Jensen. 2014. The microbial nitrogen cycle. Frontiersin Microbiology. 5: 1-2.

Wedastri, S. 2002. Isolasi dan Seleksi Azotobacter spp. Penghasil Faktor Tumbuh dan Penambat Nitrogen dari Tanah Masam. J. Ilmu Tanah dan lingkungan 3: 45-51.

Wira. 2019. Kajian Bakteri Azotobacter Pada Tanah Gambut Pada Beberapa Tipe Penggunaan Lahan Di Kelurahan Siantan Kota Pontianak. Jurnal Ilmu Tanah. Pontianak.

Widawati S, 2015. Isolasi dan Aktivitas Plant Growth Promoting Rhizobacteria (Rhizobium, Azospirillum, Azotobacter, Pseudomonas) dari Tanah Perkebunan Karet, Lampung. Jurnal Berita Biologi 14.

Widiastuti, H.,Siswanto dan Suharyanto, 2010. Karakterisasi dan Seleksi Beberapa Isolat Azotobacter sp. untuk meningkatkan Perkecambahan Benih dan Pertumbuhan Tanaman. Buletin Plasma Nutfah Vol.16 (2).

Yuleli. 2009. Penggunaan Beberapa Jenis fungi untuk meningkatkan PertumbuhanTanaman Karet (Hevea brasiliensi) di Tanah Gambut. Tesis. Sekolah Pasca Sarjana Universitas Sumatera Utara. Medan.

White, D. 1995. The Physiology and Biochemistry of Procaryotes. Oxford University Press, USA. 